\title{
FACTORS RESPONSIBLE FOR YIELD GAP OF WHEAT AT FARMERS' FIELD IN TWO DISTRICTS OF BANGLADESH
}

\author{
M. A. Kashem1', M. A. Momen Miah', M. A. Islam and P. C. Roy ${ }^{2}$ \\ Department of Agricultural Extension and Education, Bangladesh Agricultural University \\ Mymensingh-2202, Bangladesh
}

\begin{abstract}
The main purpose of the research was to identify factors responsible for yield gap in wheat production. Eighteen (18) experiments were conducted in two major wheat growing districts Rangpur and Dinajpur in two consecutive years. The selected varieties for the conducted research were Prodip, Satabdi and Sourav. All the experiments were established in farmers' fields providing all recommendations for wheat production. It was observed that yield gap varied with the variety and farmers to farmers and location to location. The overall yield gap of Prodip was the highest (18.43 percent) followed by Sourav (18.15 percent) and Satabdi (17.45 percent). Yield gaps of all the wheat varieties under study were higher in Rangpur site than Dinajpur site. The practice gap was the highest in gypsum application (69 percent) followed by boron (67 percent), sowing time (40 percent). Practice gaps in the application of MoP, TSP and irrigation were almost equal, 40 percent, 37 percent, and 36 percent respectively. Late sowing, non use of dolomite and micro nutrients (zinc and boron) in wheat yield with sub-optimal doses of phosphatic and potash fertilizers were the main reasons for yield gap. Adoption of short duration T. aman variety and optimal doses of chemical fertilizers with micro nutrients in wheat field could minimize this gap to a greater extent. Preventive measures against bird attack after sowing of seeds for optimum plant population would have impact in narrow down this yield gap as well.
\end{abstract}

Key Words: Yield gap, Wheat, Bangladesh

\section{INTRODUCTION}

Wheat is one of the main cereal crops is the world as well as in Bangladesh. It is considered to very important crop in several ways. It is grown in more than 240 million hectares in the world, an area larger than that of any other crop (Hanson et. al., 1982). It is important cereal crops with respect to both acreage and production and currently it ranked second among the cereals in Bangladesh. It contributes more calories and protein than any other food crop. Presently, it constitutes about 15 percent of the staple cereal food of Bangladesh and it is the staple food for about one million people in as many as 43

\footnotetext{
1 Professor, 2Research Officer, HEQEP Project, Department of Agricultural Extension and Education,
} Bangladesh Agricultural University, Mymensingh-2202, Bangladesh 
countries, providing 20 percent of the total food calories (Taslim, 1999). The annual production of wheat in Bangladesh is about 0.90 million tons which is cultivated in 0.38 million hectares of land with an average yield of $2.39 \mathrm{t} / \mathrm{ha}$ (BBS, 2011). This yield is very low compared to the yield obtained by the popular varieties in the research stations as well as the farmers' field demonstrations.

Generally adoption of modern technology and production practices vary across the farmers. Performances of varieties vary significantly from research station to farmers' field, even wide variations in yields are observed among the farmers. The factors of production are not used properly at farmers' level. Variation in different items of production package is mainly responsible for such kind of yield gap. Amount and quality of different inputs used and other management vary form one farmer to another. Thus, the potential yield level at farmers' field is not achieved in many cases. Sometimes farmers are found to be interested to cultivate crops with traditional management practices. Farmers cultivating HYVs of different crops also do not follow the recommended practices. As a result, the differences between potential yield and yield under farmers' practice are widened. The management practices and input use are likely to be influenced by various socio-economic factors. Keeping these facts in mind, the present study has been undertaken to fulfill the following specific objectives:

i. To quantify the yield gaps of wheat between achievable yield at researcher supervised farmers' plot and non-supervised plot;

ii. To identify the management related factors responsible for yield gap of wheat with their relative contribution; and

iii. To ascertain constraints faced by the farmers in cultivating wheat.

\section{METHODOLOGY}

In order to compare the wheat yield between maximum attainable yield and farm-level yield, in addition to research data, the empirical field data were also collected from two selected major wheat growing areas for two consecutive years. The wheat growing areas were the Sadar Upazila of Dinajpur district and Gangachara Upazila of Rangpur district. In total of 18 research plots were set up in farmers' field in order to assess the achievable yield of the wheat varieties. Nine research plots were set up in Dinajpur Sadar Upazila of Dinajpur district, while 09 research plots in Gangachara Upazila of Rangpur district. The wheat varieties were: Shatabdi, Shourav, and Prodip. The research plots were jointly conducted, monitored and supervised by the concerned farmers, SAAOs (DAE personnel) and researchers.

In order to compare the yield between the research plots and farmers' actual yield, field data were collected from the wheat growers of the selected Upazilas. Data were, however, collected from the sample rather than population. Random sampling procedures were used for determining the proportionate samples from the population. 


\section{Measurement of yield gap}

Yield gap of a variety was measured on the basis of the difference between the achievable yield $(\mathrm{kg} / \mathrm{ha})$ of research plot yield and farmer's actual yield $(\mathrm{kg} / \mathrm{ha})$ obtained at the farmers' plot and then compared it to the percentage of achievable yield. Thus, the yield gap of a variety could vary from 0 to $100 \%$. The following formula was used in this regards:

Yield gap of a farmer $=\frac{\sum_{i=1}^{n}\left(P_{i}-Y_{i}\right)}{P_{i}} \times 100$

Where,

$P_{i}=$ Achievable yield (obtained at research plots) of a particular variety; and

$\mathrm{Y}_{\mathrm{i}}=$ Actual yield the same variety harvested by a farmer.

\section{Determining the practice gap in wheat cultivation}

Yield of any crop depends on employment of some management practices. Managing all of the practices at optimum level might produce highest yield of a certain modern rice and wheat variety. But due to socioeconomic conditions in Bangladesh, farmers are not in a position to manage all the practices in a full swing rather they often apply sub-optimal level of these practices in wheat cultivation that resulted a gap between achievable yield and farmer's actual yield. Seed rate, seed quality, sowing time, irrigation and application of fertilizers (urea, TSP, MoP, gypsum and Boron) at the recommended dozes are regarded as yield determining factors, while practice gap for each yield determining factor, however, was measured on the basis of difference between recommendation and actual application. The formula used in this regard was as follows:

$$
\text { Deviation proportion } \mathrm{G}=\frac{R-A}{R}
$$

Where,

$G$ = gap;

$\mathrm{R}=$ Recommended practices for the variety; and

$A=$ Actual practices done for the same variety.

As for example, the recommended dose of seed rate of a wheat variety was $120 \mathrm{~kg} / \mathrm{ha}$. Hence, the practice gap index for seed rate of a farmer in wheat cultivation was measured by the following formula:

Practice gap index for seed rate of wheat cultivation $=\frac{\sum_{i=1}^{n} A_{i} \times G_{i}}{\sum_{i=1}^{n} A_{i}} \times 100$

Where,

$\mathrm{A}_{1}=$ Actual seed rate of a particular variety sowing in the first plot;

$\mathrm{A}_{2}=$ Actual seed rate of a particular variety sowing in the second plot;

$\mathrm{A}_{3}=$ Actual seed rate of a particular variety sowing in the third plot;

$\mathrm{G}_{1}=$ Deviation proportion for the first plot; 
$\mathrm{G}_{2}=$ Deviation proportion for the second plot; and

$\mathrm{G}_{3}=$ Deviation proportion for the third plot.

The same formulae were followed in computing practice gap indices in wheat cultivation. Seed rate, seed quality, sowing time, irrigation and application of fertilizers (urea, TSP, $\mathrm{MoP}$, gypsum and Boron) were considered for wheat production. The recommendations that were used as the basis of deviation during calculation of practice gap have been presented in Table 1.

Table 1. Recommendation used for the calculation of practice gaps in wheat cultivation

\begin{tabular}{|c|c|c|c|c|c|c|c|}
\hline \multirow[t]{2}{*}{ Crop } & \multicolumn{7}{|c|}{ Yield determinant practices } \\
\hline & $\begin{array}{c}\text { Seed rate } \\
(\mathrm{kg} / \mathrm{ha})\end{array}$ & Sowing time & $\begin{array}{c}\text { Urea } \\
(\mathrm{kg} / \mathrm{ha})\end{array}$ & $\begin{array}{c}\text { TSP } \\
(\mathrm{kg} / \mathrm{ha}\end{array}$ & $\begin{array}{c}\text { MoP } \\
(\mathrm{kg} / \mathrm{ha})\end{array}$ & $\begin{array}{c}\text { Gypsum } \\
\text { (kg/ha) }\end{array}$ & $\begin{array}{c}\text { Boron } \\
(\mathrm{Kg} / \mathrm{ha})\end{array}$ \\
\hline Prodip & 120 & $15^{\text {th }}$ to $30^{\text {th }}$ Nov & 175 & 175 & 110 & 110 & 7 \\
\hline Satabdi & 120 & $15^{\text {th }}$ to $30^{\text {th }}$ Nov. & 175 & 175 & 110 & 110 & 7 \\
\hline Sourav & 120 & $15^{\text {th }}$ to $30^{\text {th }}$ Nov. & 175 & 175 & 110 & 110 & 7 \\
\hline
\end{tabular}

Source: DAE, 2003

\section{FINDINGS AND DISCUSSION}

\section{Yield gap of wheat at rangpur (Gangachara) and Dinajpur (Dinajpur sadar)}

Nine research plots on wheat varieties of Prodip, Satabdi, and Sourav were set up in Dinajpur Sadar Upazila of Dinajpur district, while 09 research plots of these varieties were set up in Gangachara Upazila of Rangpur district. The research plot yield, farmers' actual yield, mean yield gap of these varieties along with standard deviation have been presented in Table 2.

Table 2. Achievable yield and farmers' actual yield of wheat at different locations

\begin{tabular}{|c|c|c|c|c|c|c|c|c|c|c|}
\hline \multirow{3}{*}{ 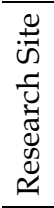 } & \multirow[t]{3}{*}{ Yield of wheat } & \multicolumn{9}{|c|}{$\begin{array}{l}\text { Variety wise achievable yield and farmers actual average yield } \\
\qquad(\mathrm{kg} / \mathrm{ha})\end{array}$} \\
\hline & & \multicolumn{3}{|c|}{ Prodip } & \multicolumn{3}{|c|}{ Satabdi } & \multicolumn{3}{|c|}{ Sourav } \\
\hline & & $\begin{array}{l}\text { 1st } \\
\text { Year }\end{array}$ & $\begin{array}{l}\text { 2nd } \\
\text { Year }\end{array}$ & Mean & $\begin{array}{l}\text { 1st } \\
\text { Year }\end{array}$ & $\begin{array}{l}\text { 2nd } \\
\text { Year }\end{array}$ & Mean & $\begin{array}{l}\text { 1st } \\
\text { Year }\end{array}$ & $\begin{array}{l}\text { 2nd } \\
\text { Year }\end{array}$ & Mean \\
\hline \multirow{3}{*}{ 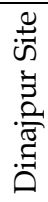 } & $\begin{array}{l}\text { Achieva } \\
\text { (Resear }\end{array}$ & 4365 & 4395 & 4380 & 4210 & 4260 & 4235 & 3965 & 3995 & 3980 \\
\hline & Farmers' actual yield & 3629 & 3681 & 3655 & 3468 & 3568 & 3518 & 3252 & 3382 & 3317 \\
\hline & yield gap (\%) & 16.86 & 16.24 & 16.55 & 17.62 & 16.24 & 16.93 & 17.98 & 15.34 & 16.66 \\
\hline \multirow{4}{*}{ 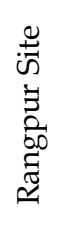 } & $\begin{array}{l}\text { Achievable yield } \\
\text { (Research plot yield) }\end{array}$ & 4345 & 4379 & 4362 & 4185 & 4215 & 4200 & 3890 & 3910 & 3900 \\
\hline & Farmers' ac & 3434 & 3518 & 3476 & 3416 & 3475 & 3446 & 3188 & 3080 & 3134 \\
\hline & Yield gap (\%) & 20.96 & 19.66 & 20.31 & 18.37 & 17.55 & 17.96 & 18.04 & 21.22 & 19.63 \\
\hline & Overall yield gap (\%) & & 18.43 & & & $\mathbf{1 7 . 4 5}$ & & & 18.15 & \\
\hline
\end{tabular}


The overall yield gap of Prodip was the highest (18.43 percent) followed by Sourav (18.15 percent) and Satabdi (17.45 percent). The findings of Table 2 reveals that the variety Prodip had the highest yield gap at Rangpur site than any other varieties. However, the yield gaps were reduced in $2^{\text {nd }}$ years in case of all the varieties in both sites.

\section{Practice gap in cultivation of wheat}

Practice gaps in wheat cultivation by the farmers were ascertained. The findings are presented in Table 3. The findings indicate that the highest practice gap by the farmers in wheat cultivation was in case of gypsum followed by use of boron and sowing time of wheat. Practice gap in seed source was much more higher in Rangpur site than Dinajpur site; 63 percent compared to 37 per cent. This may be due to the fact that the farmers of Dinajpur probably had far better access to WRC for collecting good quality wheat seeds than the farmers of Rangpur site. The practice gaps in using gypsum, boron and $\mathrm{MoP}$ in Rangpur site were also higher than Dinajpur site.

Table 3. Farmers' practice gaps in wheat cultivation

\begin{tabular}{|c|c|c|c|c|c|c|c|c|}
\hline \multirow{2}{*}{$\begin{array}{l}\text { Gaps in } \\
\text { Practices }\end{array}$} & \multirow[t]{2}{*}{ Categories } & \multicolumn{2}{|c|}{ Dinajpur site } & \multicolumn{2}{|c|}{ Rangpur site } & \multirow{2}{*}{$\begin{array}{c}\text { Total no. } \\
\text { and } \% \\
\text { farmers }\end{array}$} & \multirow{2}{*}{$\begin{array}{c}\text { Mean } \\
(\%)\end{array}$} & \multirow{2}{*}{$\begin{array}{l}\text { Standard } \\
\text { deviation }\end{array}$} \\
\hline & & $\begin{array}{c}\% \\
\text { farmers }\end{array}$ & $\begin{array}{c}\text { Mean } \\
(\%)\end{array}$ & $\begin{array}{c}\% \\
\text { farmers }\end{array}$ & $\begin{array}{c}\text { Mean } \\
(\%)\end{array}$ & & & \\
\hline \multirow[t]{4}{*}{ 1. Seed rate } & No gap (0 \%) & 16 & 9.54 & 17 & 8.30 & 25.0 & 8.92 & 7.93 \\
\hline & Low gap (1-12 \%) & 58 & & 21 & & 50.0 & & \\
\hline & Medium gap (13-24\%) & 20 & & 10 & & 20.0 & & \\
\hline & $\begin{array}{l}\text { High gap ( } 25 \% \text { and } \\
\text { above) }\end{array}$ & 6 & & 2 & & 5.0 & & \\
\hline \multirow{4}{*}{ 2. Seed source } & No gap (0 \%) & 28 & 36.66 & 0 & 62.66 & 14.0 & 21.39 & 27.22 \\
\hline & Low gap $(33.33 \%)$ & 34 & & 52 & & 43.0 & & \\
\hline & Medium gap (66.66 \%) & 38 & & 8 & & 23.0 & & \\
\hline & High gap $(100 \%)$ & 0 & & 40 & & 20.0 & & \\
\hline \multirow[t]{4}{*}{ 3. Sowing time } & No gap (0 \%) & 0 & 42.40 & 24 & 38.00 & 12.0 & 40.20 & 26.43 \\
\hline & Low gap (1-33 \%) & 32 & & 22 & & 27.0 & & \\
\hline & Medium gap (33.01-66 \%) & 54 & & 38 & & 46.0 & & \\
\hline & $\begin{array}{l}\text { High gap (66.01 \% and } \\
\text { above) }\end{array}$ & 14 & & 16 & & 15.0 & & \\
\hline \multirow[t]{4}{*}{ 4. Irrigation } & No gap (0\%) & 32 & 35.08 & 30 & 36.40 & 31.0 & 35.74 & 31.55 \\
\hline & Low gap (33.33 \%) & 40 & & 40 & & 40.0 & & \\
\hline & Medium gap (66.66 \%) & 18 & & 20 & & 19.0 & & \\
\hline & High gap $(100 \%)$ & 10 & & 10 & & 10.0 & & \\
\hline \multirow{4}{*}{$\begin{array}{l}\text { 5. Urea at final } \\
\text { land } \\
\text { preparation }\end{array}$} & No gap $(0 \%)$ & 22 & 28.14 & 18 & 27.80 & 20.0 & 27.97 & 18.99 \\
\hline & Low gap $(1-23 \%)$ & 12 & & 18 & & 15.0 & & \\
\hline & Medium gap (23.01-46 \%) & 50 & & 52 & & 51.0 & & \\
\hline & $\begin{array}{l}\text { High gap ( } 46.01 \% \text { and } \\
\text { above) }\end{array}$ & 16 & & 12 & & 14.0 & & \\
\hline \multirow{4}{*}{$\begin{array}{l}\text { 6. Urea top } \\
\text { dressing }\end{array}$} & No gap (0 \%) & 36 & 14.38 & 34 & 14.06 & 35.0 & 14.44 & 13.24 \\
\hline & Low gap (1-14 \%) & 18 & & 18 & & 18.0 & & \\
\hline & Medium gap (14.01-28 \%) & 26 & & 30 & & 28.0 & & \\
\hline & $\begin{array}{l}\text { High gap }(28.01 \% \text { and } \\
\text { above) }\end{array}$ & 20 & & 18 & & 19.0 & & \\
\hline
\end{tabular}




\begin{tabular}{|c|c|c|c|c|c|c|c|c|}
\hline \multirow{2}{*}{$\begin{array}{l}\text { Gaps in } \\
\text { Practices }\end{array}$} & \multirow[t]{2}{*}{ Categories } & \multicolumn{2}{|c|}{ Dinajpur site } & \multicolumn{2}{|c|}{ Rangpur site } & \multirow{2}{*}{$\begin{array}{c}\text { Total no. } \\
\text { and } \% \\
\text { farmers }\end{array}$} & \multirow{2}{*}{$\begin{array}{c}\text { Mean } \\
(\%)\end{array}$} & \multirow{2}{*}{$\begin{array}{l}\text { Standard } \\
\text { deviation }\end{array}$} \\
\hline & & $\begin{array}{c}\% \\
\text { farmers } \\
\end{array}$ & $\begin{array}{c}\text { Mean } \\
(\%)\end{array}$ & \begin{tabular}{c|}
$\%$ \\
farmers
\end{tabular} & $\begin{array}{c}\text { Mean } \\
(\%) \\
\end{array}$ & & & \\
\hline \multirow{4}{*}{$\begin{array}{l}\text { 7. TSP } \\
\text { application }\end{array}$} & No gap (0 \%) & 72 & 36.58 & 70 & 36.84 & 0 & 36.71 & 22.72 \\
\hline & Low gap (10-40 \%) & 20 & & 22 & & 71.0 & & \\
\hline & Medium gap (40.01-70 \%) & 8 & & 8 & & 21.0 & & \\
\hline & $\begin{array}{l}\text { High gap }(70.01 \% \text { and } \\
\text { above) }\end{array}$ & 0 & & 0 & & 8.0 & & \\
\hline \multirow{4}{*}{$\begin{array}{l}\text { 8. MoP } \\
\text { application }\end{array}$} & No gap (0\%) & 8 & 38.44 & 8 & 40.88 & 8.0 & 39.66 & 25.83 \\
\hline & Low gap $(1-33 \%)$ & 42 & & 24 & & 33.0 & & \\
\hline & Medium gap (33.01-66 \%) & 36 & & 58 & & 47.0 & & \\
\hline & $\begin{array}{l}\text { High gap }(66.01 \% \text { and } \\
\text { above) }\end{array}$ & 14 & & 10 & & 12.0 & & \\
\hline \multirow{4}{*}{$\begin{array}{l}\text { 9. Gypsum } \\
\text { application }\end{array}$} & No gap (0\%) & 28 & 68.02 & 28 & 70.10 & 28.0 & 69.06 & 33.87 \\
\hline & Low gap (1-33 \%) & 22 & & 22 & & 22.0 & & \\
\hline & Medium gap (33.01-66 \%) & 50 & & 50 & & 50.0 & & \\
\hline & $\begin{array}{l}\text { High gap ( } 66.011 \% \text { and } \\
\text { above) }\end{array}$ & 0 & & 0 & & 28.0 & & \\
\hline \multirow[t]{4}{*}{ 10. Boron } & No gap (0\%) & 26 & 63.02 & 12 & 71.42 & 19.0 & 67.22 & 42.21 \\
\hline & Low gap (1-33 \%) & 14 & & 16 & & 15.0 & & \\
\hline & Medium gap (33.01-66 \%) & 2 & & 10 & & 6.0 & & \\
\hline & $\begin{array}{l}\text { High gap }(66.01 \% \text { and } \\
\text { above) }\end{array}$ & 58 & & 62 & & 60.0 & & \\
\hline
\end{tabular}

Correlation between different practice gaps in wheat cultivation and yield gaps in wheat

Correlation co-efficients were computed to ascertain the relationships different practice gaps with the yield gaps of wheat. The findings have been presented in Table 4.

Table 4. Relationships of the practice gaps in wheat cultivation by the farmers with the yield gaps in wheat

\begin{tabular}{l|c}
\hline \multicolumn{1}{c|}{ Practice gaps in wheat cultivation } & Correlation co-efficient $(\mathrm{r})$ \\
\hline 1. Seed rate & $0.778^{* * *}$ \\
2. Seed quality & $0.576^{* * *}$ \\
3. Sowing time & $0.891^{* * *}$ \\
4. Quantity of irrigation & $0.933^{* * *}$ \\
5. Urea at final land preparation & $0.822^{* * *}$ \\
6. Urea top dressing & $0.458^{* *}$ \\
7. TSP application & $0.540^{* * *}$ \\
8. MoP application & $0.555^{* * *}$ \\
9. Gypsum application & $0.464^{* * *}$ \\
10. Boron & $0.520^{* * *}$ \\
\hline
\end{tabular}

*** Significant at $\mathrm{P}<0.001$ level of probability 
The findings presented in Table 3 show that all the practice gaps by the farmers in wheat cultivation had significant positive relationships with the yield gaps in wheat. This meant that yield gaps of wheat increased with the increase of practice in wheat cultivation.

\section{Relationships of selected characteristics of farmers with yield gaps in wheat cultivation}

In order to assess the relationships between the selected characteristics of wheat growers and their yield gaps in wheat, correlation co-efficients were computed. The findings have been presented in Table 5 .

Table 5. Correlation between the selected characteristics of the wheat growers and their yield gaps in wheat

\begin{tabular}{lc}
\hline \multicolumn{1}{c|}{ Selected Characteristics } & Correlation co-efficients $(\mathrm{r})$ \\
\hline 1. Age & .096 \\
2. Level of education & $-.253^{*}$ \\
3. Family size & .074 \\
4. Farm size & .041 \\
5. Farming experience & $-.418^{* *}$ \\
6. Agricultural Knowledge & $-.381^{* *}$ \\
7. Innovativeness &.$- .208^{*}$ \\
8. Attitude towards modern agricultural & $-.245^{*}$ \\
technologies & $-.421^{* *}$ \\
9. Use of information sources & -.110 \\
10. Risk orientation & $-.237^{*}$ \\
11. Decision making ability & \\
\hline
\end{tabular}

* Significant at $\mathrm{P}<0.05$ level of probability; ** Significant at $\mathrm{P}<0.001$ level of probability

The findings of Table 5 shows that level of education, farming experience, agricultural knowledge, innovativeness, attitude towards technologies, and decision making ability of the wheat growers had significant negative relationships with their yield gaps in wheat production.

\section{Yield gap influencing factors in wheat}

Linear multiple regression co-efficient were computed in order to determine the influential factors leading to yield gaps in wheat. The findings have been presented in Table 6. The findings reveal that only four factors (application of irrigation, boron, urea and seed sowing gap) contributed about 84 percent variation of the yield gaps in wheat cultivation.

\section{Constraints in wheat cultivation}

As of rice similar procedures were followed to compute problem facing index (PFI) in case of wheat. The findings are presented in Table 7. The top 05 constraints as PFI were: delayed sowing due to preceding crops, high cost of quality seeds, low plant population 
due to massive attack of birds, high price of fertilizers, and poor knowledge about modern wheat locality.

Table 6. Linear multiple regression coefficients of yield gap influencing factors of wheat production

\begin{tabular}{l|c|c|c|c|c}
\hline Yield gap influencing factors in wheat & \multicolumn{2}{|c|}{$\begin{array}{c}\text { Unstandardized } \\
\text { Coefficients }\end{array}$} & $\begin{array}{c}\text { Standardized } \\
\text { Coefficients }\end{array}$ & t-value & $\begin{array}{c}\text { Level of } \\
\text { significance }\end{array}$ \\
\cline { 2 - 5 } & $\mathrm{B}$ & $\begin{array}{c}\text { Std. } \\
\text { Error }\end{array}$ & Beta & & \\
\hline (Constant) & -3.033 & 1.270 & & -2.389 & .019 \\
1. Irrigation application gap & .207 & .036 & .498 & 5.736 & .000 \\
2. Boron application gap & .041 & .014 & .131 & 2.948 & .004 \\
3. Urea application gap at top dressing & .086 & .040 & .087 & 2.159 & .034 \\
4. Seed sowing gap & .080 & .039 & .161 & 2.044 & .044 \\
R2 Value $=\mathbf{0 . 8 3 9}$ & & & $\mathrm{F}=88.72$ & $\mathrm{P}=0.000$
\end{tabular}

Table 7. Constraints in wheat cultivation as mentioned by the farmers $(n=100)$

\begin{tabular}{|c|c|c|c|c|c|c|}
\hline $\begin{array}{l}\text { Sl. } \\
\text { No. }\end{array}$ & Statement of constraints & High & Medium & Low & Not at all & CFI \\
\hline 1 & Delayed sowing due to preceding crops & 44 & 32 & 8 & 16 & 220 \\
\hline 2 & High cost of quality seeds & 40 & 36 & 12 & 12 & 216 \\
\hline 3 & $\begin{array}{l}\text { Low plant population due to massive } \\
\text { attack of birds }\end{array}$ & 41 & 32 & 11 & 16 & 214 \\
\hline 4 & High price of fertilizers & 38 & 35 & 12 & 15 & 211 \\
\hline 5 & $\begin{array}{l}\text { Inadequate knowledge about modern } \\
\text { wheat cultivation }\end{array}$ & 37 & 32 & 15 & 16 & 206 \\
\hline 6 & Attack of rats & 34 & 33 & 22 & 11 & 201 \\
\hline 7 & $\begin{array}{l}\text { Insufficient cooperation of field } \\
\text { extension workers }\end{array}$ & 33 & 34 & 20 & 13 & 200 \\
\hline 8 & Inadequate moisture in soil & 31 & 36 & 18 & 15 & 198 \\
\hline 9 & $\begin{array}{l}\text { Insufficient credit facilities during wheat } \\
\text { cultivation }\end{array}$ & 28 & 34 & 21 & 17 & 190 \\
\hline 10 & $\begin{array}{l}\text { Low market price of wheat in harvesting } \\
\text { season }\end{array}$ & 25 & 37 & 25 & 13 & 187 \\
\hline
\end{tabular}

Farmers usually sow wheat after harvesting aman rice; in many cases farmers cannot sow wheat in exact due to delayed harvesting of aman rice. Possibly that is why this constraints appeared as the number one constraint as indicated by CFI of 220. The cost of high quality seeds WRC and BADC is relatively higher than seeds available in the local market and consequent some farmers face problems in purchasing the good quality seeds from the 
WRC and BADC. Immediately after sowing of wheat seeds some small birds of course, huge in number, eat the wheat grains and consequently the wheat plant populations are reduced in number. This leads to low yield; may be due to this reason farmers opined the massive attack of birds as one of the important constraints in wheat cultivation. Further, due to high price of fertilizers many farmers cannot buy the requisite quantity of fertilizers and in the field as recommended. That is why some farmers indicated this as the constraints in wheat cultivation.

\section{CONCLUSION}

Late sowing and unavailability of quality seeds in due time appeared as the dominant factors responsible for yield gap in wheat production. The wheat seeds are planted just after of aman rice, but due to late harvest of aman rice it is not possible to release land for wheat cultivation. The introduction of short duration aman rice can minimize the problem of late sowing of wheat. On the other hand the quality of wheat seed is an important attribute for ensuring higher yield of wheat. The quality of seed production can be enhanced by two ways: firstly growing of quality seed by government agencies and secondly cultivation of wheat for seed purposes by group of farmers in a cluster. Use of good quality seeds, proper date of sowing, less use of boron, zinc, and dolomite appeared as the important factors for the yield gaps in wheat. Hence, apart from the attempt of expanding wheat acreage, motivational training should be arranged for the wheat farmers for using recommended doses of fertilizers, especially the minor and trace elements like, boron, zinc, and dolomite (Ca.Mg carbonate).

\section{REFERENCES}

BBS. 2011. Year book of agricultural Statistics of Bangladesh. Bangladesh Bureau of Statistics. Ministry of Planning, Government of the People's Republic of Bangladesh, Dhaka, Bangladesh.

DAE. 2003. Agriculture Training Manual. Smallholder Agricultural Improvement Project (SAIP), Department of Agricultural Extension (DAE), Ministry of Agriculture, Govt. of the People's Republic of Bangladesh

Hanson, H., Borlaug, N. E. and Anderson, R. G. 1982. Wheat in the third world. West View Press, Boulder, Colorado, USA. $\mathrm{s}$

Taslim, T. 1999. Wheat production and market participation of the wheat growers in Jamalpur district. M.S. Thesis, Department of Agricultural Economics, Bangabandhu Sheikh Mujibur Rahman Agriculture University, Gazipur, Bangladesh. 